\title{
Investigating the recent drought effects on underground water resources in the province of Kurdistan from a quantitative and qualitative point of view (Case study: Dehgolan and Ghorveh plains)
}

\author{
Ebad Bashiri ${ }^{1}$, Jahanbakhsh Bashiri ${ }^{2}$, Farhad Karimi ${ }^{1}$ \\ ${ }^{1}$ Department of Water Resources, Bureau of Water Resources, Kurdistan, Kurdistan, Iran \\ ${ }^{2}$ Irrigation and Drainage Engineering, Science and Research Branch, Islamic Azad University, \\ Tehran, Iran \\ E-mail address: Bashiri_ab@yahoo.com
}

\begin{abstract}
The Ghorveh plain with an annual average rainfall of 350 millimeter and a cold and semi humid climate is located between the Dehgolan's watersheds and Chahardoli and 95 kilometers east of Sanandaj and northwest of Hamadan. From a geographic coordinates point of view it is situated between the longitudes of $47^{\circ} 38^{\prime} 52^{\prime \prime}$ to $48^{\circ} 06^{\prime} 03^{\prime \prime}$ eastern and latitudes of $35^{\circ} 02^{\prime} 22^{\prime \prime}$ to $35^{\circ} 30^{\prime} 54^{\prime \prime}$ northern. This plain leads to Mts. Darvazeh and Ebrahim Attar from south, it leads to hillside lands from the northern side, from Westside it reaches Mt. Bikheir and from the eastern part it is limited to the Dam Gaz heights. The area of the Ghorveh watershed is 1063/50 square kilometers while the area of the region under study is 197 square kilometers. Geologically speaking, it is located in the Sanadaj -Sirjan zone. The collision depth to the underground waters in the heights range bordering the plain is a maximum of 42 meters while the same rate about the river Talvar is at least zero and it is less than 5 meters in a wide range region of the eastern side of the plain. The direction of the underground water flow in the Ghorveh region is from the south west to north east. The Piezometrical water level changes compared to the western side plain has had a reduced height.The Dehgolan's plain with an annual average rainfall of 354 millimeters and a cold and semi humid climate is located in the eastern side of the city of Sanandaj between the longitudes of $47^{\circ} 08^{\prime} 00^{\prime \prime}$ to $48^{\circ} 12^{\prime} 00^{\prime \prime}$ eastern and latitudes of $35^{\circ} 00^{\prime} 00^{\prime \prime}$ to $36^{\circ} 00^{\prime} 00^{\prime \prime}$ northern. This plain is limited to not very high ridge of Shanooreh from the eastern side and it leads to the Darband Kabood heights and Abdulrahman heights from south, while it leads to Mt. Sheida and Akhikamal and Salarabad from north and then it is limited to the Khatoon heights from the west part . The area of the watershed of Dehgolan is 2250 square kilometer and the area of the region under study is 644 square kilometers. Geologically and regionally speaking, it is part of the geological - structural zone of Sanandaj - Sirjan. The general slope of the region is towards east and north east. The main river of this plain is called Talvar. The alluvial aquifer of the Dehgolan's plain is of a free type and is on average 90meters thick where in some parts thickness swells to 90 meters.
\end{abstract}

Keywords: Drought; Climate change; Underground water fluctuations 


\section{INTRODUCTION}

Since it is located in an arid and semi-arid region, Iran is in a more unfavorable water situation than the average countries of the world. The occurrence of subsequent and prolonged droughts, high water and weather fluctuations, have exacerbated the water level resources. Thus, underground water resources are considered as the main resources for the consumption water supply in different economic, social and agricultural and household consumption sectors of these areas. Recent droughts have caused the static level of underground water aquifers of the Ghorveh and Dehgolan plains to decline in the past years. The issue of water and its scarcity for such countries as Iran having arid and semi arid climate exists since times ago, thus, adequate water resources for drinking, agricultural and industrial consumption is of high importance from a quantitative and qualitative point of view. Based on conducted studies, the average raining rate in the country is 250 millimteres which is less than a third of the average annual rainfall of the world. In recent years, the phenomenon of drought has led to a sever reduction of the water levels in the country and hence, using underground waters has increased. Climatic conditions, the temporal and spatial distribution of precipitation, uncontrolled population growth, increased water consumption, extra consumption, and not observing the rules and regulations of using water, and lack of just distribution of water, threaten the country with the crisis of water scarcity and even dehydration, thereby, endangering water resources and especially underground waters. Increased agricultural, livestock and industrial activities and population increase in the past 10 years in particular, have led to an increase in the water consumption and as a result a reduction in the underground water resources and a negative balance of the aquifers of the Dehgolan and Ghorve plains. According to the fact that the only secure and permanent resource being exploitable in the region is underground waters, hence, using underground water resources of the said plains requires proper management and regular planning. The requirement of a poroper management is to recognize the qualitative and quantitative status of the underground water resources. In this research, after climatic investigations, geology, hydrology and hydro geochemistry of the area were investigated. In the end, given the existing status, appropriate guidelines were recommended in order to qualitatively and quantitatively promote the underground water resources of the plains.

\section{GEOGRAPHIC LOCATION AND COMMUNICATION ROUTES OF THE GHORVE PLAIN}

The Ghorveh plain with an annual average rainfall of 350 millimeter and a cold and semi humid climate is located between the Dehgolan's watersheds and Chahardoli and 95 kilometers east of Sanandaj and northwest of Hamadan . From a geographic coordinates point of view it is situated between the longitudes of $47^{\circ} 38^{\prime} 52^{\prime \prime}$ to $48^{\circ} 06^{\prime} 03^{\prime \prime}$ eastern and latitudes of $35^{\circ} 02^{\prime} 22^{\prime \prime}$ to $35^{\circ} 30^{\prime} 54^{\prime \prime}$ northern. This plain leads to Mts. Darvazeh and Ebrahim Attar from south, it leads to hillside lands from the northern side, from Westside it reaches Mt. Bikheir and from the eastern part it is limited to the Dam Gaz heights. The area of the Ghorveh watershed is 1063/50 square kilometers while the area of the region under study is 197 square kilometers. Geologically speaking, it is located in the Sanadaj - Sirjan zone.

The collision depth to the underground waters in the heights range bordering the plain is a maximum of 42 meters while the same rate about the river Talvar is at least zero and it is less than 5 meters in a wide range region of the eastern side of the plain. The maximum 
height of this region is located in the southern parts of the watershed which is 3145 meters of the sea level (Mt. Bagar), and the minimum height of this range is 1684 meters of the sea level(the end place of the plain around the Shadiabad station over river Shoor). In conducting the paper, climatic precipitation of the area under study, in accordance with the importance of the timing and raining level in the hydrologic calculations as well as calculations relating to water balance and the necessity of having adequate information and statistics with regards to the said area, we began to analyze the current stations statistics around the area. In the first step, the stations of the area were identified and analyzed.

In this area, there are 41 stations whose their climatic parameters have been collected. From among this number, 18 stations are related to the meteorological department, 3 of them are synoptic stations while 15 of them are rain gauge stations. The raining distribution of one area has a close relation to the geographic and general status features of that region. The level of rainfall has direct relations with a height rise. However, sometimes it has been observed that in a region raining does not follow a clear relationship with height. In other words, in similar heights, different raining have been observed or some extra height factors are involved in the raining of the area. Given the location of the stations and their distance from the range under study, 8 of them were used to formulate a raining gradient .

\section{GENERAL PROPERTIES OF THE DEHGOLAN'S PLAIN}

The Dehgolan's plain with an annual average rainfall of 354 millimeters and a cold and semi humid climate is located in the eastern side of the city of Sanandaj between the longitudes of $47^{\circ} 08^{\prime} 00^{\prime \prime}$ to $48^{\circ} 12^{\prime} 00^{\prime \prime}$ eastern and latitudes of $35^{\circ} 00^{\prime} 00^{\prime \prime}$ to $36^{\circ} 00^{\prime} 00^{\prime \prime}$ northern. This plain is limited to not very high ridge of Shanooreh from the eastern side and it leads to the Darband Kabood heights and Abdulrahman heights from south, while it leads to Mt. Sheida and Akhikamal and Salarabad from north and then it is limited to the Khatoon heights from the west part. The area of the watershed of Dehgolan is 2250 square kilometer and the area of the region under study is 644 square kilometers. Geologically and regionally speaking, it is part of the geological - structural zone of Sanandaj - Sirjan. The general slope of the region is towards east and north east. The main river of this plain is called Talvar. The alluvial aquifer of the Dehgolan's plain is of a free type and is on average 90meters thick where in some parts thickness swells to 90 meters. The lowest point of height in the area under study is located in the northern border with less than 1700 meters of the sea level while the highest point of height is situated in the south eastern part of Mt. Kholane with more than 2800 meters of the sea level. The most important population are is situated in the city and the city of Dehgolan is located almost in the center of the area. People's language is Kurdish. Access to the are under study is possible through the asphalt route of Tehran-SanandajHemedan where they are considered as the main routes of the country. The economy of the area is based on livestock and agriculture and main products are wheat, barley, legumes and vegetables as well as livestock products. Major rivers of the watershed of the Dehgolan's area are Talvar and Sangesyah ensuing from the heights overlooking the area understudy. River Talvar ensues from the Shakhcharmoo heights in the south of the area and receiving seasonal springs waters they will run in the northern part. River Sangesyah originates from the Pirgheis heights in the south of the area and run in the northern part in order that they get out of the area. Geomorphologic ally, this plain is an even plain that is distinguished with an the northwest - southeast expansion and with the length of around 60 kilometers and width of 36 kilometers between the heights around it like Mt. Some Ali, Abdulrahman, Darband, 
Panjeali, Noorbesar, Ebrahim Attar, Sangesyah, Sangesefid, and Bikheir from other plains of Kurdistan like Ghorveh plain in the east, Sorkhab plain in the west, and Khosroabad and Darghyath in the north. Major rivers of the plain are: Charkhge bayan, (from west to east), Dehgolan(from southwest to north-northeast), Sangesyah(from south to notrth-north east), and Sahgesyah (from south to north) which feed numerous waterways from different locations. The network of feeding waterways for this plain is various and forms like parallel and dendrite and vertical waterways can be seen in there. Of course the main river of this plain is called Talvar whose water regime is due to raining, snow melting followed by underground aquifers drainage. Talver after receiving the level streams of the subsidiary watersheds in a place called Hsaasn Abad station (Dehgolan area end point)goes out of the region. Rivers Ghorichay, Barike and Chamgoore are among the other rivers that run in the length of south and southwest to the north and north east in the plain. The general slope of the plain is towards northeast and east and the height balance of 1900 can be considered as the separating border of the mountain and plain. Also, igneous rocks and transformation as well as dolomite lime stones in the south of the plain have led to the creation of heights with steep slope. The reason of this issue is the relatively high resistance of the igneous stones and lime stones against erosion.

\section{GHORVEH HYDROLOGY}

From a hydrological point of view, the structures of this region due to having numerous cracks and fractures as well as orifices are considered as permeable. Permeated waters in these stones appear in the form of numerous springs in the margin of valleys that being used. The regional metamorphic stones affected in the surface parts by the weathering process are chopped and numerous small springs with weak water discharge originate from them. Marty deposits in the PlioPleistones sediments will reduce their permeability and because of this, they are not of high importance despite having considerable thickness from the water resources point of view. From among the current maps around this plain, the geological tertiary era structures, because of having evaporative salts impact negatively on the chemical quality of underground waters. Subsidiary phenomena of volcanic activities of the current century like the exit of carbonated mineral springs from the deep faults and fractures contribute largely to the bad quality of underground waters. The thickness of the quaternary deposits in the alluvial of Golali, Ploosarkan, Meimanatabad and Avangan is between 25 to a maximum of 150 meters while the same rate for the alluvial of Sanginabad, Divzand, Gharekhani and Zarine is a maximum of 85 meters. The maximum thickness of quaternary deposits has been around 150 meters reduced to 10 meters in the northern part of the plain. On average, it has been estimated as 70 meters.

The latitudinal resistance of the alluvial deposits is between 1000 to $3000 \mathrm{ohm}$ square meter indicating the existence of underground water reservoir in a wide range of the plain. The collision depth to underground waters in the foothill of the heights bordering the plain is a maximum of 42 meters while that of the river Talvar limits is a m minimum of zero and it is less than 5 meters in the eastern part of the plain. The area of this region whose underground water resources are drained by evaporation and direct drainage by the river Shoor is 60 square kilometers. The collision depth to underground waters in the central part of the plain is around 10 to 20 meters while it is over 20 meters in the south and northwest of Ghorve, reducing towards the north, reaching less than 5 meters. The depth of the underground water in the central part and eastern margin of the plain is around 10 meters and the same rate for 
the western part of the plain is between 30 to 40 meters. The collision depth to underground waters in region as big as $50 \%$ of the plain surface is less than 5 meters.

\section{EXPLOITATION STATUS OF THE UNDERGROUND WATER RESOURCES}

Exploring the underground water resources is carried out by deep and semi deep wells aqueducts and springs. On the basis of geological shears of the region and geophysical results, the main aquifer of the Ghorve plain expands along the half south of the Ghorve watershed in between the heights and the center of Mozafarabad-Aminabad and Kharile villages. In other regions of this area, there is no substantial aquifer.

Statistics of the underground waters and roads in particular, has identified the exploitation level of these resources in different seasons and due to the exploitation hours in different seasons, the amount of well drainage has been calculated. On the other hand, in the past two years, the resources indicating the quantitative and qualitative features have been under statistics four times and in spring and fall no change has ever been seen in the level of exploitation. Because of this fact, statistics of the quantitative and qualitative resources were not used.

\section{WELLS}

Wells are dense in the south and east of Ghorve and due to this the underground water level has seen a large decline in this area. There are 731 wells in the Ghorve watershed where 463 of them are active and 165 of them are deserted due to some different reasons. As many as 36 wells are used for the drinking water supply, 538 wells for the agricultural consumption while 67 of them are excavated for the industrial and livestock use. The drainage of the above mentioned wells reaches an amount of 38/33 million cubic meters per annum. From this huge amount, 8 million cubic meters is used for drinking consumption, 29 million cubic meters is used by the agricultural sector while $1 / 3$ million cubic meters is used for the industrial sector. The depth of the wells in the watershed varies between 1 to 120 cubic meters.

The minimum water discharge of the wells is $0 / 4$ liter per second and the maximum of it in the Fadak cooperation company well located in the Sanginabad reaches 62 liters per second. The range of the well can be divided into two parts. 498 wells have been excavated in the center of Mozafarabad and Sheikhjafar villages and continues until the east of the river Chamshoor (around the village of Baghlooje and Delbaran) and annually 35/8 million cubic meters are taken of this aquifer. From this center northwards, along with the river Chamshoor till the place of collision of the river Chamtalvar 233 wells have been excavated where annually around $2 / 5$ million cubic meters is taken out of this aquifer. It should be noted that, from a sum of 731 deep and semi deep wells in the area, 566 wells are active, and the rest (165 wells) are deserted with faulty equipment. Wells in the area of Delbaran and Ghzeljakand, are often excavated in the tuff deposits $\left(\mathrm{P}^{\mathrm{t}}\right)$.

The average depth of these wells is 7 meters while their water discharge is around $5 / 5$ liters per second. This subject indicates an inappropriate water discharge of the tuff deposits. Wells excavated around the rivers and Zarrinabad and Allahyari range have a mean depth of 10 meters and water discharge of less than 3 liters per second. 


\section{AQUEDUCTS}

There are 41 aqueducts in the region excavated mostly in the Delbaran, Serishabad, and Ilanloo regions. Aqueducts' water discharge is very low. The water discharge of 24 aqueducts is between $0 / 5$ to 5 liters per second while the same rate for the 12 aqueducts is between 5 to 10 liters per second. The Khalesane aqueduct 's water $\backslash$ discharge is a second is 10 liters while that of the new Karise aqueduct is 22 liters per second. The annual aqueduct drainage in 2009 was around 5/6 million cubic meters.

\section{SPRINGS}

There are 293 springs in the watershed. Springs are often located in the south of the plain bordering the heights in the end point of Orye valley and Vihej. Water discharge of these springs is too low and have generally agricultural consumption. 93 of the springs produce less than a liter in a second, 170 of them produce between 1 to 5 liters per second, 23 springs produce between 5 to 10 liters in a second while 7 of them produce 11 to 20 liters inn a second. Kani Ghanbar spring has a water discharge of 30 liters in a second.

These springs are fed by the south heights. Springs that are located around the River Chamshoor usually play the role of drainage.

\section{HYDROLOGY OF DEHGOLAN'S PLAIN}

In this part of the discussion, hydrologic features of the aquifer, including the type of the aquifer, underground water balance and temporal and spatial changes, flowing direction, hydraulic slope, exit and entry fronts, hydrodynamic aquifer coefficient, natural feeding and drainage of the aquifer and the exploitation of it are going to be discussed.

\section{THICKNESS OF UNDERGROUND WATER (ALLUVIUM) AND TYPE OF DEPOSITS}

To discover the thickness of the underground aquifer and type of sediments, it is necessary that geophysical information, well measurement (well gauge) and excavation be used. Since, in here there were no precise geophysical statistics, hence, determining the exact thickness of the aquifer of the Dehgolan's plain was not possible. Investigating the geological $\log$ of the explorative wells of Khalil Abad and south of Dehgolan reaffirmed this, indicating that the thickness of the alluvium of this region is between 90 to 120 meters. Investigating the maps of the physical resistance of the Dehgolan's plain indicated that in this region three strata graphic studies, including alluvia sediments (old and new) with special resistances of 30 to $100 \mathrm{ohm}$ meters, conductor sediments that are a combination of older layers of the quaternary period and the third period with the resistance of less than $20 \mathrm{ohm}$ meters and lastly the resistant floor stones of the volcanic layers genus were carried out.

On this basis, the highest thickness was identifiable in the southern and south western parts affected by the resistant floor stones. The existence of material with the electrical resistance of over $50 \mathrm{ohm}$ meters in the south parts of the plain is affirmed. Also, the central 
and northeastern parts of the plain involve material with the electrical resistance of lower than $50 \mathrm{ohm}$ meters (indicating the existence of fine grain sediments).

\section{INVESTIGATING THE UNDERGROUND WATERS LEVEL FLUCTUATIONS (HYDROGRAPH) OF THE OBSERVATIONAL WELLS}

In the region under study, the yearly drainage and feeding amounts of the aquifer varies. This contributes significantly to the annual fluctuations of the underground waters of the region. Thus, in order to investigate the static level fluctuations of the aquifer of this region, 52 observational wells were used in the Dehgolan-Ghorve plain. These wells' statistics with regards to the water level reading have been provided since October 1987.

\section{UNDERGROUND WATER DEPTH CHANGES}

In order to investigate the underground water depth fluctuations in the region of one aquifer, it is necessary that underground water co depth curve map during the humid and dry periods of the region indicating the minimum and maximum indices of the underground water depth or in other words, indicating the annual feeding and draining amounts and impacts arising thereof be formulated. In the beginning of the statistical period, the least statistic of the underground water collision bordering the north of the plain is less than 4 meters (around Ganji, Shahabya, Dehrashi, Hajipamoogh, Talvar, Krondan, Sarab, Shabani). While in the end of a statistical period, due to uncontrolled decline, the water level depth in districts of Hajipamoogh and Shabani is less than 8 meters and in other regions mentioned the same rate is deeper. Table 1, shows the grouping underground water level depth for the minimum and maximum periods of the statistical periods. On this ground in the maximum period, $85 \%$ of the wells have a depth of less than 20 meters. The rate in none of the wells reaches more than 50 meters. While in the minimum period, $75 \%$ of the wells are deep between 20 to 40 meters and 4 wells have a depth of more than 50 meters. Generally speaking, the direction of the underground water flow is from the heights of the two sides of the plain towards the main rivers of the region and in fact towards the draining river of the underground water. Thus, the overall direction of the underground waters is from west and south of the plain towards the north and northeast.

Table 1. The grouping underground water level depth for the minimum and maximum periods of the statistical periods.

\begin{tabular}{|c|c|c|c|c|}
\hline \multirow{2}{*}{ Water level depth } & \multicolumn{2}{|c|}{ Maximum period (March 1996) } & \multicolumn{2}{c|}{ Minimum period (September 2009) } \\
\cline { 2 - 5 } & Number of wells & $\begin{array}{c}\text { Percentage of } \\
\text { total }\end{array}$ & Number of wells & Percentage of total \\
\hline$>50$ & 0 & 0.0 & 4 & 7.7 \\
\hline $40-50$ & 1 & 1.9 & {[} & 3.8 \\
\hline $30-40$ & 2 & 3.8 & 13 & 25.0 \\
\hline $20-30$ & 5 & 9.6 & 7 & 13.5 \\
\hline
\end{tabular}




\begin{tabular}{|c|c|c|c|c|}
\hline $10-20$ & 18 & 34.6 & 19 & 36.5 \\
\hline $5-10$ & 10 & 19.2 & 7 & 13.5 \\
\hline$<5$ & 16 & 30.8 & 0 & 0.0 \\
\hline & 52 & 100 & 52 & 100 \\
\hline
\end{tabular}

\section{EXPLORATIVE STUDIES}

Explorative studies in the water resources studies are generally surface geophysics studies, explorative excavations, well log, tracing, and pumping experiments. Studies carried out in the Dehgolan region include geo electric studies, explorative well log, and pumping experiments. The explorative studies having been conducted, the thickness and the way alluvia sediments are changed, the genus of floor stone, qualitative and quantitative status of the aquifer as well as the hydrodynamic coefficients of the aquifer can be determined. According to the explorative well log status of the excavated place in the Dehgolan's plain, it can be concluded that:

a) Excavation log shows that the plain sediments are generally formed of the depth levels of 20-35, meters of the alluvium with a high percentage of silt and clay and from this depth downwards, the log contains coarse material of gravel and sand.

b) Fine and coarse grain units are repeated subsequently, and do not follow a special order in different points of the plain and as a result, the aquifer is not separated.

c) Collision depth to the floor stone has happened only in one instance and its genus is of igneous while deeper wells in other places have not collided with the floor stones.

Table 2. Summary of estimated transferable information and coefficients in the explorative wells of the region of Dehgolan - Ghorve (watershed of Dehgolan).

\begin{tabular}{|c|c|c|c|c|}
\hline No. & Name of place & $\begin{array}{c}\text { Water discharge } \\
\text { (Liter per second) }\end{array}$ & $\begin{array}{c}\text { Transferable } \\
\text { coefficient (square } \\
\text { meter per day) }\end{array}$ & Observations \\
\hline 1 & Kani Ein Ali & 30 & 1000 & \\
\hline 2 & Ghorve Chai & 20 & 661 & \\
\hline 3 & Haji Pamogh & 20 & 1174 & \\
\hline 4 & Zaghe & 30 & 1405 & \\
\hline 5 & Zaghe & 20 & 400 & \\
\hline 6 & Dehrashid & 30 & 800 & \\
\hline 7 & Sarab & 30 & 914 & \\
\hline 8 & Dehgolan & 30 & 1442 & \\
\hline 9 & Cheraghabad & 60 & & \\
\hline
\end{tabular}




\begin{tabular}{|c|c|c|c|}
\hline 10 & Karim abad & 35 & 992 \\
\hline 11 & Mobarakabad & 35 & 1044 \\
\hline 12 & Saeed abad & 30 & 1250 \\
\hline 13 & Abbarik & 20 & 342 \\
\hline 14 & Hasan abad & 25 & 527 \\
\hline 15 & Javanmardabad & 18 & 1200 \\
\hline 16 & Abbasjoob & 25 & 300 \\
\hline 17 & Aliaabal & 30 & 1100 \\
\hline 18 & Ghamloo & 15 & 1128 \\
\hline 19 & Kazemabad & 30 & 500 \\
\hline 20 & Tazehabad & 25 & 1200 \\
\hline 21 & Kongare & 36 & 1287 \\
\hline 22 & Selsele & 35 & 1469 \\
\hline 23 & Kamal abad & 34 & 878 \\
\hline 24 & Tazeabad & 35 & 1990 \\
\hline 25 & Avangan & 39 & 1177 \\
\hline 26 & Shahnoore & 36 & 1667 \\
\hline
\end{tabular}

\section{HYDROCHEMISTRY OF UNDERGROUND WATERS OF THE GHORVE PLAIN UNDERGROUND WATER QUALITY}

The quality of the underground water of the Ghorve plain, using the 14 well information as shown in the table with suitable diversity has been investigated. Sampling of the wells in the years between 2004 to 2012 and the results of the years 2005 and 2006 extracted directly from the identified resources are presented in Tables.

The degree of the underground water salts and scope of its changes for different seasons is so low. The reason is the feeding of the aquifer from the transformation and igneous stones as well as the limes stones of the south of this region.

The least of underground salt level is related to the southern part of the aquifer fed from the south heights of Sanginabad and Uriye valley and Vihej. To the contrary, the highest salt is related to the northern parts of the aquifer that is affected by the MeioPlioescene $\left(\mathrm{Pl}^{\mathrm{m}}\right)$ sediments. Changes in the electrical conductivity of the water and chloride ion are as follow: 


\section{Piper Diagram for dehgholan sample}
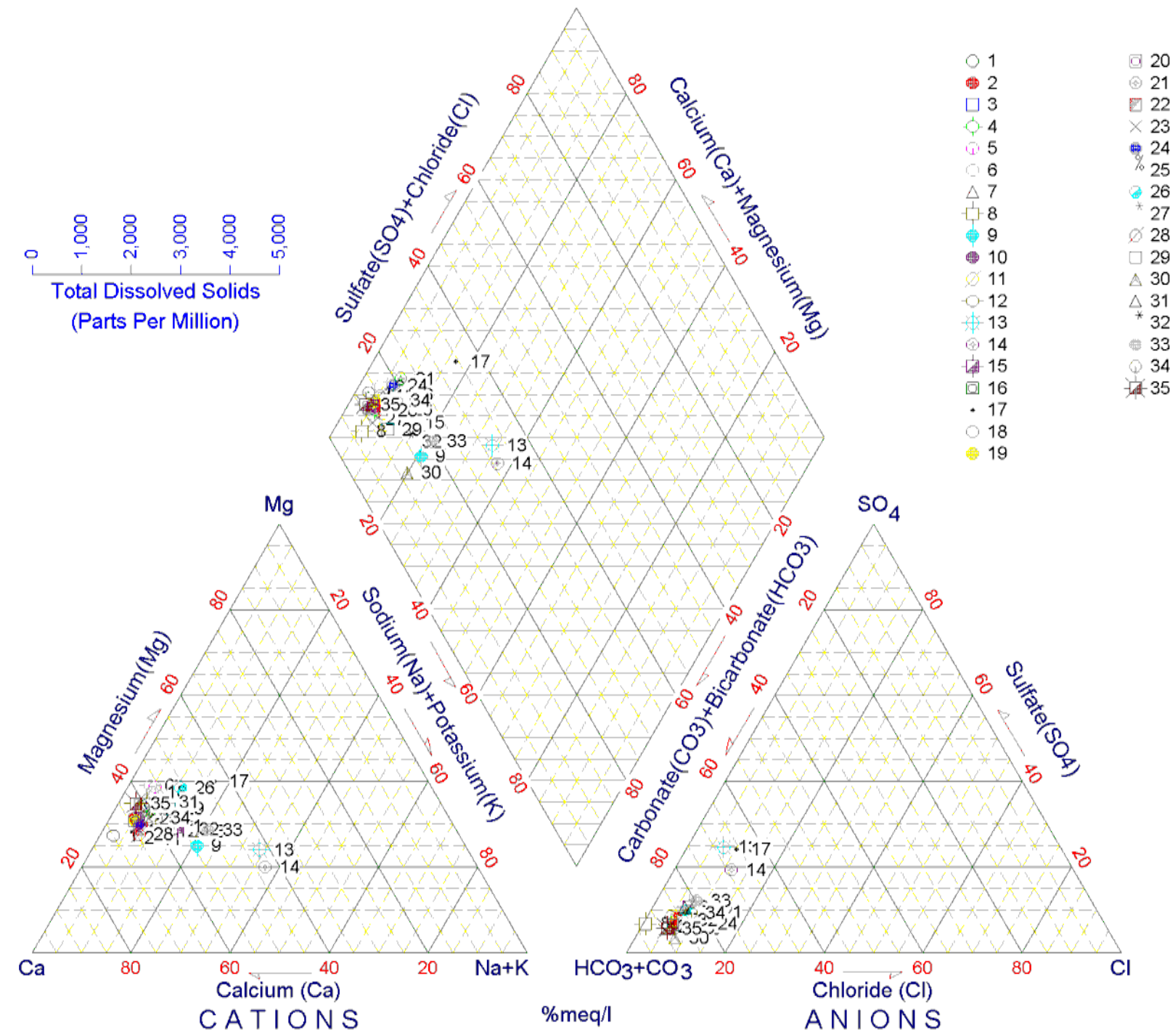

Graph 1. Presentation of the chemical analysis results of the Dehgolan's plain on the Piper curve.

\section{DISCUSSION}

Ghorve plain: The Ghorveh plain with an annual average rainfall of 350 millimeter and a cold and semi humid climate is located between the Dehgolan's watersheds and Chahardoli and 95 kilometers east of Sanandaj and northwest of Hamadan. From a geographic coordinates point of view it is situated between the longitudes of $47^{\circ} 38^{\prime} 52^{\prime \prime}$ to $48^{\circ} 06^{\prime} 03^{\prime \prime}$ eastern and latitudes of $35^{\circ} 02^{\prime} 22^{\prime \prime}$ to $35^{\circ} 30^{\prime} 54^{\prime \prime}$ northern. This plain leads to 
Mts. Darvazeh and Ebrahim Attar from south, it leads to hillside lands from the northern side, from Westside it reaches Mt. Bikheir and from the eastern part it is limited to the Dam Gaz heights. The area of the Ghorveh watershed is 1063/50 square kilometers while the area of the region under study is 197 square kilometers. Geologically speaking, it is located in the Sanadaj - Sirjan zone. The collision depth to the underground waters in the heights range bordering the plain is a maximum of 42 meters while the same rate about the river Talvar is at least zero and it is less than 5 meters in a wide range region of the eastern side of the plain.

The direction of the underground water flow in the Ghorveh region is from the south west to north east. The Piezometrical water level changes compared to the western side plain has had a reduced height . Geologically and regionally speaking, it is part of the geological structural zone of Sanandaj - Sirjan. Monthly average temperature varies between - 4/2 centigrade in February to 24/6 centigrade in July. The average relative humidity of Ghorve is $42 \%$ and the average of evaporation in Tashtak in around 1848 millimeters in the year while the annual raining average is around 320-350 millimeters. The maximum number of rainy days annually is 36 days in the eastern parts while, the same rate is $55 / 5$ days for the western parts and the southern and northern parts have 47 days of rainy days.

The region under study, in terms of morphology, has high mountains in the north (Mt. Darvaze , Mt. Ebrahim Attarwith a height of 2793 meters ) and steep valleys (Uriye and Vihej valleys) that from these two valleys two water canals of Uriye and Vihej enter into the plain and then lead to the well known river of Chashmshoor. The region has a slow morphology in the north. The southern parts of the plain consist of transformative stones like schist, amphibolites, marble and igneous masses with different combinations. The region under study is divided into three parts where the region is located in the eastern and south eastern parts. The oldest evident sediments in this region are of Permian sediments that have expanded little and are situated below the second period outcrop with eccentricity gradient. Carbonated stones in this section have been transformed and have crystallized under the process of being marble, thereby becoming marble. The transformation of these sediments is because of the infiltration of igneous masses that have come up during previous Cimmerian orogeny. The quality of the Ghorve aquifer underground water is suitable for the agricultural, industrial and drinking consumption. hence there is no limitations for the utility. However, bordering the Chamshoor river, due to the entrance of water from mineral springs containing large amounts of salts followed by $\mathrm{H}_{2} \mathrm{~S}$ gas, the quality of water has become unpleasant. The aquifer's area of the plain is around 197 kilometers. Collision depth to underground waters in the foothills of the heights bordering the plain is a maximum of 42 meters and around the Talvar river the rate is a minimum of zero while in a wide range of the eastern part of the plain the same rate is less than 5 meters. In the central parts the collision depth is 10 to 20 meters, in the south and northwest it is more than 20 meters, reducing towards the north, reaching less than 5 meters.

The underground water depth in the central and eastern borders of the plian is around 10 meters and the rate for the western part is between 30 to 40 meters. Collision depth to the underground waters in an area as big as $50 \%$ of the plain level is less than 5 meters. The total volume of underground water entering is $23 / 15$ while water exiting is $3 / 84$ million cubic meters. The mean water transferability in the alluvia of the southern borders of the aquifer is around 400 square meters per day and it has been estimated in the exit borders of it as 50 square meters. From a sum of 23/15 million cubic meters of volume of water entering, 13/5 million cubic meters in the humid periods ( 7 months) and 9/65 million cubic meters in the dry period ( 5 months) enter the range. The least water electrical conductivity is related to the south and south western part of the plain while the highest rate of electrical conductivity is in 
the north east. The trend of underground water's feeding from south heights of Sanginabad and Uriye valley is well identifiable. The central part curves of the plain are related to the amounts of electrical conductivity of 450-500 micro Siemens per centimeters. Bordering the north and north east of the plain where the aquifer is located in proximity with the $\mathrm{Pl}^{\mathrm{m}}$ constructs, the electrical conductivity is from 600 to 700 micro Siemens per centimeters.

The least amount of chloride ion in the Ghorve aquifer in the entrance section of the plain from the Uriye and Vihej valleys is 5 milligrams per liter while the same rate for the borders of the south heights of Sanginabad reaches 8 milligrams per liter. The highest amount of chloride ion by as much as 15 milligrams per liter is found in the north of the AminabadMozafarabad center while in the eastern borders of the plain around Hajiabad is 10 milligrams in liter.

Dehgolan plain: The Dehgolan's plain with an annual average rainfall of 354 millimeters and a cold and semi humid climate is located in the eastern side of the city of Sanandaj between the longitudes of $47^{\circ} 08^{\prime} 00^{\prime \prime}$ to $48^{\circ} 12^{\prime} 00^{\prime \prime}$ eastern and latitudes of $35^{\circ} 00^{\prime}$ $00^{\prime \prime}$ to $36^{\circ} 00^{\prime} 00^{\prime \prime}$ northern. This plain is limited to not very high ridge of Shanooreh from the eastern side and it leads to the Darband Kabood heights and Abdulrahman heights from south, while it leads to Mt. Sheida and Akhikamal and Salarabad from north and then it is limited to the Khatoon heights from the west part. The area of the watershed of Dehgolan is 2250 square kilometer and the area of the region under study is 644 square kilometers. Geologically and regionally speaking, it is part of the geological - structural zone of Sanandaj - Sirjan.

The general slope of the region is towards east and north east. The main river of this plain is called Talvar. The alluvial aquifer of the Dehgolan's plain is of a free type and is on average 90meters thick where in some parts thickness swells to 90 meters.

The average monthly temperature is a minimum of -32 centigrade in January that can increase to around 39/2 centigrade in June while the yearly long term average is $9 / 8$ centigrade. Annual mean level of humidity is $56 \%$ where the highest relative humidity reaches $75 \%$ in January and the least amount of this parameter is $46 \%$ in October. The average wind speed in the year is $3 / 2$ meter per second.

Based on balance maps of underground waters, the general direction of the underground in the Dehgolan aquifer is from the eastern, southern and western parts of the plain towards middle and northern parts. The hydraulic gradient in the exit and middle regions of the plain is between $1-2$ in thousand while in the feeding areas, the hydraulic gradient is around 1/01. Generally, the hydraulic gradient reduces from western, southern and southeastern parts to the northern parts of the plain and in line with the underground water flow. Transferability coefficient variations is from a minimum of 300 square meters in a day to more than 1950 square meters in a day (southeast of the plain around Tazeabad Khaliliabad village).

Generally, the coefficient level in the south and foothill areas is more than the northern parts. Results also, reveals that the underground water level follows a topographic status that is flowing from the south parts in numbers of 1900-1905 meters, western from an altitude of 1960 meters, eastern from an altitude of 1875 meters of the sea level towards the central areas in the altitude of less than 1765 meters of the sea level.

Generally speaking, the maximum of water depth in the highest water level is more than 56 meters in the central areas. The least water depth in the exit part (around Shabani villige) reaches less than 5 meters. 


\section{RECOMMENDATIONS}

1. In order to prevent from any qualitative and quantitative crises in the water resources of Ghorve and Dehgolan plains, it $9 \mathrm{~s}$ recommended that measures be taken with regards to the prohibition of new well excavations.

2. Determining the drought calendar of different agricultural stages for each produce and meeting the water needs by the time of drought.

3. Establishing powerful outfits in the region understudy in order to address the impermissible wrong excavations and controlling these excavations in the region under study precisely.

4. Installing the smart meters on the agricultural wells and justly allocating the water resources.

5. Implementing the pressured irrigation systems to economize water consumption.

6. Training farmers of the region to optimally apply the water resources.

7. Offering propagation advice suitable for the produces in accordance with the obtainable water by the time of drought.

8. Establishing multi function dams and implementing artificial feeding projects in the regions entering the plain to control for the flooding and optimally using the surplus waters in a humid era.

\section{References}

[1] Afzal S., I. Ahmad, M. Younas, M. Din Zahid, M. H. Atique Khan, A. and K. Ali, Environment International 26 (2000) 87-96.

[2] Fetter C. W., Applied Hydrology, 3th ed. Macmillan Pub1., New York, 2001.

[3] Sikdar P. K., S. S. Sarkar, S. Palchoudhury, Journal of Asian Earth Sciences 19(19) (2001) 579-594.

[4] Bower Hermann, Underground waters hydrology, trans by. Ahmadlatifi Sedigh, Sahand Sanati University, First version, Tabriz, 1995.

[5] Ghayoor Hasanali, Expansion and frequency of droughts in Iran, Doctoral thesis, Tarbyat Modarres, Tehran, 1996.

[6] Jean Lew, Surface waters hydrology, trans by. Majid Zahedi.

[7] Kastani G., Investigating and utilizing underground waters, trans by Davood Chehrazi, Vol, 1, Tarbyat Modarres, Tehran 1978.

[8] Khosh Aklagh Faramarz, Investigating monthly Li, wet and drought patterns Iran, Geographic studies, Ashoora institute, No. 45, Mashhad 2001.

[9] Kordvani, Parviz, Geohydrology, Tehran University Publications, 1991.

[10] Meteriology department site : WWW.irimet.net/drought

[11] Statistics of evaporation of the evaporation gauge stations in Kurdistanfrom 1991 to 2009, Department of water, First section, Anas publication, Tabriz 1999.

[12] Statistics of the meteorology departments of the government from 1990 to 2010, Tehran and Kurdistan. 
[13] Western part water, 2009, A report of estimation of changes to the underground water volume of the Ghorve plain, Chahardoli, and Dehgolan.

[14] Western part water, 2009, A report of water balance of the Ghorve plain.

( Received 21 October 2013; accepted 25 October 2013 ) 